\title{
Brief Chronology
}

1759 Birth at La Neuville-au-Pont of Joseph-François Baudelaire, father of Charles.

1793 Birth in London of Caroline Archenbault Defayis, poet's mother.

1819 Marriage of Joseph-François Baudelaire and Caroline Defayis.

18219 April: birth of Charles-Pierre Baudelaire.

1827 Death of Charles Baudelaire's (CB's) father.

1828 Caroline Baudelaire marries Lieutenant-Colonel Jacques Aupick.

1832 CB and his mother go to Lyon where Aupick is stationed.

1836 Return to Paris. CB attends the College Louis-le-Grand.

1839 Expulsion from the lycée Louis-le-Grand.

1841 CB sets out on a voyage meant to take him to Calcutta. Stops at Reunion and Mauritius, then refuses to go any further. He returns to France, arriving February 15, 1842.

1842 Inherits 100,000 francs from his father's estate.

1844 CB's extravagant spending leads his family to create a conseil de famille which appoints Narcisse Ancelle trustee of his fortune.

1845 Publication of his review of the Salon, and of a poem, "A une dame créôle." First translations of the works of Poe begin to appear in the French press. 30 June: $C B$ attempts suicide by stabbing himself.

1846 Publication of his Salon of 1846.

1847 Publication of his short story "La Fanfarlo."

1848 February Revolution and uprisings of June. CB collaborates on a newspaper, Le Salut public, of which only two numbers appear. 15 July: publication of CB's first translation of Poe, Magnetic Revelation.

1851 Publication of his first study of wine and hashish, which contains prose versions of verse poems on wine to appear in Les Fleurs du mal. 2 December: coup d'état in which Louis-Napoléon declares himself emperor.

1852 March and April: publication in La Revue de Paris of CB's first study of Poe. 


$$
\text { xii - Brief Chronology }
$$

1855 June: La Revue des deux mondes publishes eighteen poems under the title Les Fleurs du mal. June: publication of the first of CB's prose poems, "Crépuscule" and "La Solitude."

1856 March: publication of CB's translations of Poe called Histoires extraordinaires.

1857 January-February: trial of Flaubert's novel Madame Bovary. 8 March: publication of CB's second volume of translations of Poe's short stories. 27 April: death of General Aupick. 25 June: publication of Les Fleurs du mal. 7 July: Les Fleurs du mal accused of being an outrage to public decency. 20 August: $\mathrm{CB}$ condemned to pay fine of 300 francs and suppress six of the poems.

185813 May: Publication of CB's translation of Poe's novel Arthur Gordon Pym.

1859 First notes for Mon Coeur mis à nu (My Heart Laid Bare).

1860 January: CB sells Poulet-Malassis and de Broise the second edition of Les Fleurs $d u$ mal, his study of the artificial paradises, and his articles of literary and art criticism. 13 January: suffers first attack of illness. May: publication of Les Paradis artificiels (The Artifical Paradises).

1861 February: second edition of Les Fleurs du mal. 15 June-15 August: La Revue fantaisiste publishes nine of the ten prose articles that make up the Réflexions sur quelques uns de mes contemporains (Reflections on some of my contemporaries). 11 December: CB presents his candidacy for the Academy.

186313 January: Baudelaire gives Hetzel for the sum of 1,200 francs the exclusive rights to publish his Petits Poèmes en prose and Les Fleurs du mal previously sold to Poulet-Malassis.

186424 April: CB arrives in Brussels. 2 May: lecture on Delacroix. 11 May: lecture on Gautier. 12, 23 May and 3 June: lectures on artificial stimulants. 13 June: CB reads from his works. 25 December: under the title "Le Spleen de Paris" La Revue de Paris publishes 6 prose poems.

186516 March: publication of CB's translation of Poe, Histoires grotesques et sérieuses (Tales, grotesque and serious).

1866 Around 15 March, CB visits Namur and falls on to the ground in the church. 22-23 March: his condition worsens. 30 March: paralysis of the right side. 31 March: Le Parnasse contemporain publishes Nouvelles Fleurs du mal (New Flowers of Evil). 2 July: CB brought back to Paris.

186731 August: death of CB. 2 September: burial in the Montparnasse cemetery.

1868 December: Michel Lévy begins publishing CB’s complete works. 